\title{
Can A Transnational Law Approach Offer A Better Understanding of International Law's Contribution to Sustainable Hydropower Projects? A Test Case from the Mekong River Basin
}

\author{
Laure-Elise Mayard \\ Northumbria Business and Law School, Newcastle upon Tyne \\ laure-elise.mayard@northumbria.ac.uk
}

\begin{abstract}
Hydropower regulation involves an increasingly complex set of actors, scales and legal regimes. The role that international law plays in regulating hydropower, and other sustainable development issues, is challenged by this pluralism because of international law's restrictive traditional theoretical framework, which appears to be ill-equipped to fully grasp and represent significant features of pluralistic regulation. A broader conceptualization of international law could create a more pluralist, holistic and integrated approach to regulation, making it more attuned to reality and to sustainable development objectives.

This article adopts a transnational law approach embracing in a more flexible manner different elements which influence regulation and which escape existing legal categories. Hydropower projects in the Lower Mekong River Basin illustrate the mismatch between regulation mainly focused on the State, investment-related actors and regimes of large projects, on the one hand, and the growing pluralism driven by the involvement of non-State actors, specificities of environmental regulation and different levels of inquiry, on the other hand. The analysis explores the 'blind spots' of international law in its regulation of hydropower projects and considers the possibilities in which a transnational law approach broadens the vision of existing international law to be more pluralist.
\end{abstract}

(C) LAURE-ELISE MAYARD, 2019 | DOI:10.1163/23527072-20191019

This is an open access article distributed under the terms of the prevailing CC-BY license at the time of publication. 


\section{Keywords}

Sustainable development - Transnational law - Integration - Hydropower - Mekong River Basin

\section{Introduction*}

International law plays an important role in regulating sustainable development related issues and policies, including poverty reduction, climate change mitigation and equality. This role prompts a reflection on the actual involvement and contribution of international law in promoting sustainable development. ${ }^{1}$ Sustainable development issues are difficult to govern since they involve an increasingly complex network of elements. Many actors (for example States, international organizations, non-governmental organizations, private and public actors) multiple scales (local, international and transnational) and several legal regimes (such as economic, environmental and human rights fields) have an influence on the regulation of sustainable development. In light of this growing plurality and complexity, sustainable development regulation has emphasized the need for integration, especially among what is seen as the three main pillars of economic growth, social well-being and environmental protection, which are to be pursued in conjunction with each other. In addition, integration within sustainable development entails inclusion on a social level, ${ }^{2}$

* The Special Issue 'International Law for the Sustainable Development Goals' is a research outcome of the 2017-2018 Workshop Series 'International Law for the Sustainable Development Goals' organised by the Department of Transboundary Legal Studies, Faculty of Law, University of Groningen. Mando Rachovitsa and Marlies Hesselman led the organisation of these workshops. The series included 8 workshops which explored the role and relevance of international law to the implementation of the Sustainable Development Goals. The Special Issue includes some of the papers presented at the workshops and papers submitted to an open Call for Papers. More information is available at https://www .rug.nl/rechten/ congressen/il4sdgs/.

1 Ben Boer et al., The Mekong: A Socio-legal Approach to River Basin Development (London: Routledge, 2015).

2 Frank Biermann, Norchika Kanie and Rakhyun E. Kim, 'Global Governance by Goal-setting: The Novel Approach of the UN Sustainable Development Goals', Current Opinion in Environmental Sustainability, 26-27: 26-31 (2017). 
meaning that everyone should be included in sustainable development as an actor or a beneficiary. ${ }^{3}$

Despite the lack of a clear definition of integration in the literature on international law, ${ }^{4}$ the notion of integration, in this context, is understood as a means to gather the different actors, scales and legal regimes involved in the regulation of sustainable development issues, in order to create a collective synergy. ${ }^{5}$ In this way, integration would both limit the adverse impacts of pluralism (e.g. conflicts, incoherencies or competition amongst several norms or actors) and ideally create convergence and an output that would be more of a coherent sum of objectives than a juxtaposition. The objective of integration within sustainable development has been operationalized and expressed most notably through the 2030 Agenda and the SDGs. ${ }^{6}$ The SDGs are a nonhierarchical list of interconnected goals, ${ }^{7}$ which aims 'to vastly improve economic, social and planetary well-being' and they aim at fostering participation to sustainable development. ${ }^{8}$ Integration is explicitly formulated in the 2030 Agenda and in the SDGs, ${ }^{9}$ as opposed to their predecessor, the Millennium Development Goals. ${ }^{10}$ In their very format, the SDGs aim at the integration

UN News, 'No-one left behind' is ethical imperative of new developmental agenda-UN deputy chief, 13 January 2016, https://news.un.org/en/story/2016/o1/519872-no-one-left-behindethical-imperative-new-development-agenda-un-deputy-chief, accessed 9 May 2019.

4 Casey Stevens, 'Scales of Integration for Sustainable Development Governance', International Journal of Sustainable Development \& World Ecology, 25/1:1-8 (2018).

Briassoulis gives a comprehensive overview of the different types of integration. See Helen Briassoulis, 'Analysis of Policy Integration: Conceptual and Methodological Considerations' in Helen Briassoulis (ed.), Policy integration for Complex Environmental Problems: The Example of Mediterranean Desertification (New York: Routledge, 2017), pp. 55-56.

David Le Blanc, 'Towards Integration at Last? The Sustainable Development Goals as a Network of Targets', DESA Working Paper No. 141 ST/ESA/2015/DWP/141, 1 March 2015, conclusion para. 1; Stevens, 'Scales of Integration for Sustainable Development Governance', p. 1.

7 Rakhyun E. Kim, 'The Nexus between International Law and the Sustainable Development Goals', Review of European, Comparative \& International Environmental Law, 25/1: 15-26 (2016), p. 20.

8 Joseph Alcamo et al., Interactions Among the Sustainable Development Goals... and Why They Are Important, Policy Brief, 12 July 2018, p. 1, http://sro.sussex.ac.uk/77086/, accessed 9 May 2019.

9 UNGA Resolution, Transforming Our World: The 2030 Agenda for Sustainable Development, UN Doc A/RES/70/1, 21 October 2015, preamble.

10 Mark Stafford-Smith et al., 'Integration: The Key to Implementing the Sustainable Development Goals', Sustainability Science, 12/6: 911-919 (2018), p. 912; Ines Boas, Frank Biermann and Norichika Kanie, 'Cross-sectoral Strategies in Global Sustainability Gover- 
of various key issues, which are divided into 17 goals and grouped within a single agenda. ${ }^{11}$ The issues are perceived as complementary, based on interdependence and connections between the themes themselves, ${ }^{12}$ where food and water are naturally associated, ${ }^{13}$ and based on the interlinkages created by the agenda and other integrative approaches. In order for the SDGs and sustainable development to be operationalized an instrument is needed to regulate by reflecting integration and synergetic interlinkages. ${ }^{14}$ Law participates in realizing policy and societal directions, like sustainable development ${ }^{15}$ and creating integration, when designed to be 'compatible, consistent and coordinated' (with policy and between themselves). ${ }^{16}$ In order then to appropriately tackle pluralism and integrate all relevant aspects within the decision-making process, international law should also be able to consider the entirety of actors, scales and regimes.

However, regulating pluralism within international law is proven to be challenging. The traditional attributes of international law, based on State sovereignty and on divides between national and international - private and public - are at odds with the flexibility and diversity required to deal with sustainable development. Whilst legal practical developments adapting to pluralism can be observed, particularly certain non-State actors gaining legal personality or recognition overtime, the aforementioned disparity is evident in legal theory. Furthermore, the complexity of regulation in sustainable development leads international law to frame issues with more manageable and simplified visions and fixed categories. First, this indicates a mismatch between legal theory and practice, but also a gap between legal theory and the pluralist reality on the ground; second, it questions the capacity of international law to contribute to integration within sustainable development.

nance: Towards a Nexus Approach', International Environmental Agreements: Politics, Law and Economics, 16/3: 449-464 (2016); David Le Blanc, 'Sustainable Development Goals and Policy Integration in the Nexus' in Felix Dodds and Jamie Bartram (eds.), The Water, Food, Energy and Climate Nexus - Challenges and an Agenda for Action (Routledge, 2016).

11 Briassoulis, 'Analysis of Policy Integration', p. 64.

12 Le Blanc, 'Towards Integration at Last?', conclusion para. 3.

13 Ibid., section on the SDGs as an Enabler for Integration, para. 4.

14 Stafford-Smith et al., 'Integration: The Key to Implementing the Sustainable Development Goals', p. 917.

15 Alhaji B. M. Marong, 'From Rio to Johannesburg: Reflections on the Role of International Legal Norms in Sustainable Development', Georgetown International Environmental Law Review, 16/1: 21-76 (2003), p. 61.

16 Briassoulis, 'Analysis of Policy Integration', p. 70. 
Within this context, this article argues that it worth considering a different theoretical approach to international law and integration, namely Transnational Law (TNL). TNL broadly refers to laws or norms that are influencing the regulation of an issue beyond and between traditionally closed categories of scales, actors, fields or the legal nature of instruments. This flexible and holistic thinking offers opportunities to analyse complex sustainable development issues such as the development of transboundary hydropower projects. Therefore, the purpose of this article is to explore if TNL can, as a new perspective on international law, sufficiently capture the range of legal issues related to the diversity of actors, scales and regime with regard to transboundary hydropower projects.

The discussion focuses on transboundary hydropower projects for several reasons. First, hydropower projects can be seen as a topic at the heart of sustainable development. Their purpose is generally to create energy and manage water resources as well as to support growth, development and climate change mitigation. ${ }^{17}$ The energy from hydropower is of key importance to the growing global demand for electricity ${ }^{18}$ and represents a crucial component of renewable energy mix. ${ }^{19}$ Hydropower projects can also provide valuable insights to assess pluralism and the goal of integration within sustainable development since they are a good example of the expansion in number and type of the actors, scales and fields involved. Hydropower projects have gradually experienced pluralism and fragmentation in the shift from State and investment-focused projects to transnational and multi-stakeholder efforts while embracing environmental and social concerns. The role accorded to international law in the regulation of hydropower projects has broadened, including investment law, environmental law and transboundary watercourses governance. Therefore, the regulation of hydropower projects provides an excellent test-case of the usefulness of a TNL framework for assessing international law's regulation of multi-dimensional issues.

The Lower Mekong River Basin is an apt case study to examine the consideration of pluralism within international law. The basin is sparking debate

17 Anik Bhaduri et al., 'Achieving Sustainable Development Goals from a Water Perspective', Frontiers in Environmental Studies, 4/64 (2016), pp. 8-9.

18 Christopher A. Scott, Mathew Kurian and James L. Wescoat Jr., 'The Water-Energy-Food Nexus: Enhancing Adaptive Capacity to Complex Global Challenges' in Mathew Kurian and Reza Ardakanian (eds.), Governing the Nexus: Water, Soil and Waste Resources Considering Global Change, (Springer International Publishing, 2015); Engelbertus Oud, 'The Evolving Context for Hydropower Development', Energy Policy, 30/14: 1215-1223 (2002).

19 Emilio F. Moran et al., 'Sustainable Hydropower in the $21^{\text {st }}$ Century', Proceedings of the National Academy of Sciences, 115/47: 11891-11898 (2018), 11893. 
on the development of hydropower. The Mekong River Basin is one of the most active basins in terms of hydropower potential and large dam constructions. ${ }^{20}$ These completed, on-going and planned hydropower developments (especially the eleven large-dams projects) on the mainstream of the Lower Mekong River Basin have caught a lot of attention concerning the way they are regulated and the recurrent negative impacts that the projects have on the environment and society. ${ }^{21}$ The situation of hydropower in the Mekong River Basin has produced, and still provides, evidence of the challenges in integrating and balancing economic, social and environmental interests. Adverse effects from these projects have already occurred to a great scale, from the loss of livelihoods, displacement, and the collapse of dams ${ }^{22}$ as well as important reduction in fish stock. Pluralism and integration are not adequately reflected in hydropower projects. Therefore, the discussion herein briefly presents the growing phenomenon of pluralism and fragmentation in hydropower projects, which is reflective of the situation in other sustainable development issues. This allows the presentation of integration as a priority for sustainable hydropower projects and the framing of hydropower issues within SDGs as propitious for integration. Secondly, the analysis highlights the limitations of international law in considering pluralism and its current application to hydropower projects on the Lower Mekong River Basin by examining existing gaps and accounting for all the relevant actors, scales and regimes to such projects. It argues that a more pluralist and holistic vision of international law would help to consider more appropriately the pluralism that pertains to large hydropower projects and sustainable development issues. The concept of TNL will be presented as an approach for re-exploring international law, by extending its scope and reflecting on its categorisation of law. Ultimately, the article seeks to highlight what TNL may add in terms of broadening the legal perspective to sustainable hydropower projects.

20 Boer et al., The Mekong: A Socio-legal Approach to River Basin Development, pp. 9-10; Moran et al., 'Sustainable Hydropower in the $21^{\text {st }}$ Century', p. 11894.

21 Jessica M. Williams, 'The Hydropower Myth', Environmental Science and Pollution Research, (2019): 1-7.

22 One example of it is the 2018 collapse of the Xe-Pian Xe-Namnoy hydro-electric project in Laos. See International Rivers, Save the Mekong Statement on the Collapse of the Xe Pian - Xe Nam Noy Hydropower Project, 30 July 2018, https://www.internationalrivers. org/resources/save-the-mekong-statement-on-the-collapse-of-the-xe-pian-xe-nam-noyhydropower-project, accessed 9 May 2019. 

within Sustainable Development and the Opportunity Presented by the SDGs

Section 2 presents the growing pluralism of actors, scales and fields within hydropower and the need for integration. The SDGs are then used to highlight hydropower's multi-dimensional and interconnected nature in order to promote integration, in hydropower and, more generally, in sustainable development issues.

Pluralism and the Multi-scalar, Multi-actor and Multi-regime Nature of Hydropower Projects

The phenomena of pluralism and fragmentation in sustainable development are evident in hydropower projects. Hydropower projects have faced a lot of criticism and controversy in their regulation due to their main focus on economic aspects of projects at the expense of the environmental and social aspects. Until recently, hydropower projects regulation reflected mostly economic and investment terms and regimes, with a strong relationship to the State, on the national level, and other economic actors relating to the financing, construction and operation of such infrastructures. ${ }^{23}$ However, public opinion regarding the negatives impact on the environment and society led hydropower regulation to go through a transition where trade-offs and the complex nature of hydropower are emphasized. ${ }^{24}$ Due to these inherent tradeoffs being considered only from an economic perspective, overall, negative impacts often occur through, for example, displacement, loss of livelihoods and destruction of ecosystems. ${ }^{25}$ Until recently, there was a long-standing competition and antagonistic relationship between energy production and social and environmental concerns, making it difficult to pursue both economic development and environmental protection. ${ }^{26}$

23 Kim Geheb, Niki West and Nathanial Matthews, "The Invisible Dam: Hydropower and its Narration in the Lao People's Democratic Republic' in Nathanial Matthews and Kim Geheb (eds.), Hydropower Development in the Mekong Region: Political, Socio-economic and Environmental Perspectives (Taylor \& Francis, 2014), p. 105.

24 Oud, 'The Evolving Context for Hydropower Development'.

25 Moran et al., 'Sustainable Hydropower in the $21^{\text {st }}$ century', pp. 11891-11892.

26 Oliver Hensengerth, 'Where Is the Power? Transnational Networks, Authority and the Dispute Over the Xayaburi Dam on the Lower Mekong Mainstream', Water International, 40/5-6: 911-928 (2015). 
The focus of hydropower policy has shifted from a more economic-focused growth $^{27}$ to the consecration of the three pillars, which sets economic, social and environmental objectives as fundamental components of sustainable development. ${ }^{28}$ However, the simultaneous pursuit of these objectives of very different - and possibly competing 29 - nature can create (or fuel) fragmentation. Fragmentation here implies that each objective considered is more or less independent and that, either the pursuit of different objectives fragments the unity of hydropower policy, or that the pursuit of these different objectives does not appear to make up a single, coherent and integrated goal. Policy-making decisions might become elusive due to a lack of clarity and coherence.

The following sub-sections divide the discussion of pluralism in hydropower into the sub-categories of actors, scales and regimes since these types of elements are distinctive components of regulation. These three categories allow a clearer look at pluralism in hydropower across the three pillars of pursuing economic, social and environmental objectives.

\subsubsection{Hydropower Projects as a Multi-actor Issue}

In addition to the State and economic and investment-related actor (e.g. foreign investors or development banks) pluralism in hydropower projects has attracted a larger pool of stakeholders which are involved and interested in hydropower.

The main actor, at the centre of hydropower projects is, first and foremost, the State, due to the national objectives of development and energy production of dams. Hydropower relates to the use and exploitation of water resources, whose management is generally entrusted to the State and is subject to the permanent sovereignty of States over their natural resources. ${ }^{30}$ Other main actors are mostly related to investment and economics because of creating - and commercializing - energy, as well as the huge costs of building and running such infrastructures. ${ }^{31}$ Considering the tremendous investment needed for

\footnotetext{
27 David Kennedy, Law and Development Economics: Toward a New Alliance (Oxford University Press, 2013).

28 UNGa Resolution, Transforming Our World: The 2030 Agenda for Sustainable Development, UN Doc A/REs/70/1, 21 October 2015, p. 1.

29 Sophie Landberg, 'Sustainable Development of Water Resources in the Mekong River Basin: Legal and Policy Implications of Dams in the Regional Context', Journal of East Asia and International Law, 5/1: 235-259 (2012), p. 258.

Unga Resolution 3171/1973, Permanent Sovereignty Over Natural Resources, UN Doc A/RES/3171, 17 December 1973 .

31 Moran et al., 'Sustainable Hydropower in the $21^{\text {st }}$ century', p. 11892.
} 
hydropower projects and, hence, trading energy, private investors, banks and companies have an important interest and role in these projects.

However, other non-economic actors are involved in, and are now recognised as part of, the regulation of hydropower projects. Bhaduri et al. describe the recent understanding that, while investment in hydropower projects generally involves States and international donors, the construction of dams affects a much larger stakeholder group, especially in a transboundary setting. ${ }^{32}$ For example, the communities and individuals affected by the projects have an interest in the protection of their survival, livelihoods, location, their access to and supply of natural resources (e.g. water) or access to infrastructures or even their sacred sites. Other types of non-economic actors that are now more often involved in hydropower are non-governmental organizations (NGOs), civil society organisations and international organisations (IOs) with various objectives. NGOs, such as International Rivers or World Wildlife Fund, and IOs, including the International Hydropower Association, are looking closely at the way hydropower projects are built and the types of impact they generate. The International Hydropower Association, for instance, has been involved in creating 'best' practice guidelines for hydropower decision-making and building, in order to prevent the negative impact mentioned earlier and address public criticism. ${ }^{33}$ As such, the types of actors interested and involved in hydropower projects are different with regard to their specific interests, their status (group or individual, having legal personality or not) and the way they participate in the process of hydropower (e.g. protesting and campaigning ${ }^{34}$ or making judicial claims). ${ }^{35}$ Their involvement in hydropower decision-making, regulation, operation or even reparation demonstrates the growing plurality of actors within hydropower.

In the context of the Lower Mekong River Basin, a broad array of actors can be found in the Mekong River Commission (MRC), an intergovernmental regional body established to manage the river basin. It includes the four Lower Mekong River riparian States (Thailand, Laos, Cambodia and Vietnam) as formal members and decision-makers. In addition, the MRC has gradually

32 Anik Bhaduri et al., 'Sustainability in the Water-Energy-Food Nexus', Water International, 4o/5-6: 723-732 (2015), p. 727 .

33 International Hydropower Association, Hydropower Sustainability Guidelines on Good International Industry Practice, 13 December 2018, https://www.hydropower.org/publications/hydropower-sustainability-guidelines, accessed 9 May 2019.

An example is the "assembly of the poor", see reference in Jakkrit Sangkhamanee, 'From Pak Mun to Xayaburi: The Backwater and Spillover of Thailand's Hydropower Politics' in Matthews and Geheb (eds.), Hydropower development in the Mekong Region, p. 85.

An example is the Niwat $v$ Electricity Generating Authority of Thailand case. See reference in Boer et al., The Mekong: A Socio-legal Approach to River Basin Development, p. 89. 
opened to non-State participants and observers, ${ }^{36}$ including financial institutions and donors, international organisations (for example, the Food and Agriculture Organisation, the Asian Development Bank) but also NGOs (for example, Oxfam or the World Wildlife Fund). ${ }^{37}$ These actors can be informed, influence and advise on matters of hydropower in the Mekong but the status and impact of such actors still remain informal and subject to member States' acceptance. An example of such advocacy can be the voluntary submission of a legal analysis of the eleven dams project on the Mekong River Basin by EarthRights International's Mekong Legal Advocacy Institute and a Cambodia Law group submitted to the MRC. ${ }^{38}$ The MRC website also suggests the gradual opening to informal actors or any 'interested stakeholder', who are allowed to submit comments, feedback and petitions during the prior consultation and Strategic Environmental Assessment (SEA) process. ${ }^{39}$ In addition to the MRC, other actors and programs gather a wide array of actors participating to and influencing hydropower regulation in the Basin. The NGO-based programme wwF Greater Mekong works on the Mekong River Basin for the sustainable use of natural resources and the protection of biodiversity while cooperating with governments, industry and NGOS.

\subsubsection{Hydropower Projects as a Multi-scalar Issue}

Hydropower decision-making has started to refer to diverse scales of regulation, transitioning from a primarily nationally-focused project to considering international, local and basin-level aspects of the projects.

Typically, hydropower projects are mainly regulated at the national scale. The geographic location of the dam within a specific sovereign territory and the considerable involvement of the host State favours regulation at the national level. As such, hydropower projects depend on national plans and regulations regarding investment, construction and trade of energy. However,

36 Janice Gray, Cameron Holley and Rosemary Rayfuse (eds.), Trans-jurisdictional Water Law and Governance (New York: Routledge, 2016), p. 49.

37 Mekong River Commission, Development Partners \& Partner Organisations, http://www .mrcmekong.org/about-mrc/development-partners-and-partner-organisations, accessed 9 May 2019.

38 Earthrights International Mekong Legal Advocacy Institute, Mekong River Dams: National Laws to Address Environmental and Human Rights Issues, and Obstacles to Enforcement, December 2009, https://earthrights.org/wp-content/uploads/publications/ Mekong-River-Dams-MLAI_o.pdf, accessed 9 May 2019.

39 Mekong River Commission, sEA Petitions and MrC Responses, http://www.mrcmekong. org/stakeholder-consultations/sea-petitions-and-mrc-responses, accessed 9 May 2019; Mekong River Commission, Stakeholder Consultations, http://www.mrcmekong.org/ stakeholder-consultations, accessed 9 May 2019. 
the scales involved in the regulation of hydropower projects are now more diversified. The international level is especially present in hydropower regulation taking in this way into account the, often, transboundary nature of the watercourses exploited or the impacts of said projects. It is now accepted that for a hydropower project to be sustainable and successful, it should consider transboundary effects and transboundary governance mechanisms, including riparian countries consultation or impact assessment. ${ }^{40}$

Human rights and environmental protection instruments are widely developed at the international level and these documents may have a direct impact on hydropower regulation. All the Lower Mekong River Basin countries are parties to the Convention on Wetlands of International Importance especially as Waterfowl Habitat and they are thus legally bound to protect wetlands, and, consequently, limit hydropower projects' negative impacts on biodiversity. ${ }^{41}$ This has a direct influence on national plans to develop hydropower but also on regional and local plans to protect wetland biodiversity and ecosystems. In addition to regulation, there are now more cross-border aspects to (national) litigation, such as suits brought against foreign companies and other international actors with the purpose of engaging their legal responsibility for the negative impacts of hydropower projects, thereby blurring the divides of borders and scales. ${ }^{42}$

Moreover, regulations at the regional and local level are also growing in importance as these scales appear to be the most appropriate, and geographically close, to the projects. The Mekong River Basin illustrates the growing development of hydropower projects discussed and facilitated at a basin and

40 Alistair Rieu-Clarke, 'Transboundary Hydropower Projects Seen Through the Lens of Three International Legal Regimes - Foreign Investment, Environmental Protection and Human Rights', International Journal of Water Governance, 3/1: 27-48 (2015), p. 29.

41 Convention on Wetlands of International Importance especially as Waterfowl Habitat (adopted 2 February 1971) 996 UnTS 14583, as amended by the Paris Protocol of 3 December 1982, and the Regina Amendments of 28 May 1987.

42 For an example of a Thai court's decision accepting jurisdiction over the case of a Thai company's project abroad see reference in Business and Human Rights Resource Center, The landmark Xayaburi Dam case in Thailand: what is at stake?, https://www .business-humanrights.org/en/the-landmark-xayaburi-dam-case-in-thailand-what-is-atstake, accessed 1 May 2019; for an example of a complaint from a Malaysian coalition of communities, NGos and csos against the Don Sahong Dam in Laos, see reference in EarthRights International, Human Rights Commission Report Highlights Lack of Accountability in Don Sahong Dam Project, https://earthrights.org/media/human-rightscommission-report-highlights-lack-of-accountability-in-don-sahong-dam-project/, accessed 1 May 2019. 
regional level, through the $\mathrm{ADB}$, the MRC as well as through joint efforts between riparian countries like Thailand and Laos.

\subsubsection{Hydropower Projects as a Multi-regimes Issue}

Finally, in terms of sectors and legal regimes involved, hydropower projects' regulation is traditionally centred on the economic and investment fields. Relevant regimes and regulations can include domestic and international investment law, contracts and loans from international developmental banks, and trade of energy regulations. Most of the applicable regulations regarding such projects draw on investment agreements and international private law contracts, which are often bilateral. ${ }^{43}$ Riparian countries, like Laos and Thailand, share a number of trading agreements on hydropower energy as an essential part of their trading relationships. ${ }^{44}$ Yet hydropower project regulation is progressively influenced by environment or social-related legal regimes. Whether at the national, regional or international level, environmental regulation is now directly referred to hydropower developments. The prime example of this is the duty to conduct an Environmental Impact Assessment (EIA). ${ }^{45}$ Within the process of elaborating a hydropower project, an EIA is meant to assess the possible consequences of a project on the environment. EIAs and other processes, such as the Strategic Environmental Impacts, are now considered of great importance to integrating diverse objectives and perspectives of a project. ${ }^{46}$ Several initiatives aiming at reconciling different objectives within hydropower are also developed at different levels and involving a variety of actors. The UN Guiding principles on business and human rights created a broad effort to prevent and address human rights abuses during business operations. ${ }^{47}$ This is a key subject for hydropower projects, in which the social costs are often criticized, and Thailand, one of the countries with the most keen interest and investment in hydropower energy in the Lower Mekong River Basin, is currently developing a National Action Plan to protect human

43 John Briscoe, 'The Changing Face of Water Infrastructure Financing in Developing Countries', International Journal of Water Resources Development, 15/3: 301-308 (1999).

44 WWF Greater Mekong, Mekong River in the Economy, November 2016, p. 120, http:// d2ouvy59podg6k.cloudfront.net/downloads/mekong_river_in_the_economy_final.pdf, accessed 9 May 2019.

45 Gilles G. Bérubé and Céline Cusson, 'The Environmental Legal and Regulatory Frameworks - Assessing Fairness and Efficiency', Energy Policy, 30/14: 1291-1298 (2002).

46 Ibid., p. 1292.

47 UN Human Rights Council, Protect, respect and remedy: a framework for business and human rights : report of the Special Representative of the Secretary-General on the Issue of Human Rights and Transnational Corporations and Other Business Enterprises, John Ruggie, UN Doc A/Hrc/8/5, 7 April 2008. 
rights. ${ }^{48}$ Another effort to reconcile economic and human rights objectives within the regulation of watercourses is the Southeast Asian regional conference and, in particular, the 'Mekong Statement' released in 2018.49 This initiative gathering various actors from NGOS, academia, indigenous groups and local civil society, aligns itself with the World Commission on Dams and the UN Guiding principles in asking for a better environmental and social protection during hydropower developments.

In addition to the diversification of the regimes and sectors focused on in hydropower regulation, the spectrum of regulatory instruments has also expanded. Whether pursuing economic, social or environmental objectives, new non-legal documents have multiplied in order to guide and inform the regulation of hydropower projects. This approach is mostly used by actors that could be described as somewhat 'secondary' but with a growing influence, including international organizations or NGOS. These types of documents may fall outside of the strict qualification of legal documents or regulatory instruments but they have a certain influence, and often reflect or respond to missing objectives, such as environmental and social aspects of sustainable development and hydropower projects. Some key voluntary initiatives applicable in the context of hydropower planning are the UN Guiding principles and the UN Global Compact; the 2003 Equator Principles for financial institutions; and the 2011 Hydropower Sustainability Assessment Protocol adopted by the International Hydropower Association. ${ }^{50}$ Interestingly, key economic and investment actors (e.g. donor agencies) have developed such non-legal guidelines relating to environmental and social objectives with the aim to influence their economic intervention in hydropower projects. ${ }^{51}$

In sum, hydropower project regulation has clearly transitioned from a limited to a varied number of actors, scales and legal regimes. For Bérubé and Cusson, it is now 'the ultimate goal (...) to reconcile the three fundamental

48 National Action Plans on Business and Human Rights, Thailand, https://globalnaps.org/ country/thailand, accessed 23 April 2019.

Forest People Programme, Protect human rights in trans-boundary investments - the message from the 2018 SEA conference on Human Rights and Business, 13 September 2018, https://www.forestpeoples.org/en/node/50282, accessed 9 May 2019.

Boer et al., The Mekong: A Socio-legal Approach to River Basin Development, pp.173-174; Kofi Annan, Business and the UN: A Global Compact of Shared Values and Principles, 31 January 1999, World Economic Forum, Davos, Switzerland, reprinted in Vital Speeches of the Day 65 (9) (15 February 1999) and see the Global Compact website for the principles at www.unglobalcompact.org; 'Equator Principles (EP), 4 June 2003, available at www .equator-principles.com; International Hydropower Association, Hydropower Sustainability Assessment Protocol, (London November 2010). 
principles framing hydropower development: the promotion of human rights, the protection of the environment and the right to economic development'.52 In order to achieve this reconciliation or integration, hydropower regulation has to be inclusive of all the influential actors, scales and fields discussed earlier.

\subsection{Hydropower Pluralism Framed within the SDGs Agenda and the Overarching Aim of Integration}

Hydropower regulation is pluralist and fragmented with regard to the actors, scales and regimes it involves. The need for integration called upon matches the overall objective of integration within sustainable development and the SDGs.

The case of hydropower projects' regulation is very relevant to the overall achievement of the SDGs, bearing in mind the topic of interlinkages among issues within the SDGs and integration of sustainable development. The field of hydropower development is related to several of the SDGs in its climate change action (SDG 13); renewable energies targets (SDG 7); the use of water resources and land (SDGs 6 and 15); secondary purposes for irrigation and food production (SDG 2); improving economic growth (SDG 8); sustainable cities and communities (SDG 11); and life below water (SDG 14). The United Nations Department of Economic and Social Affairs (UNDESA) estimates that ' 125 of 169 targets included in the SDGs are linked to energy. That is more than two-thirds of all targets. ${ }^{3}$ Hydropower maintains a strong link with the SDGs agenda, its targets and shares the aim for integration of sustainable development. Therefore, hydropower projects are set in an overall policy context propitious for pluralism and integration, considering the aim and momentum for integration and the coincidence with the multi-dimension of the SDGs.

\section{International Law's Limitations in Engaging with Pluralism in} Hydropower Regulation

Section 3 introduces the limitations of international law in embracing pluralism and fragmentation, and discusses how international law restricts the integration of important actors, scales and regimes within hydropower

\footnotetext{
$5^{2} \quad$ Bérubé and Cusson,'The Environmental Legal and Regulatory Frameworks', p. 1292.

53 United Nations Economic and Social Commission for Asia and the Pacific, Accelerating $S D G 7$ Achievement: Policy Briefs in support of the first SDG 7 Review at the UN High-Level Political Forum 2018, Policy Brief No 19, Achieving SDG 7 in Asia and the Pacific, 2018, p. 153, https://sustainabledevelopment.un.org/content/documents/18041SDG7_Policy_Brief. pdf, accessed 9 May 2019.
} 
regulation. The limited transcription of hydropower projects from an international legal theory perspective is gradually being balanced by spontaneous and heterogeneous developments in international legal practice thereby calling for a reinvestigation of the theoretical vision of international law.

The General Limitations of Traditional International Legal Theory Facing Pluralism and Fragmentation

Sustainable development regulation has put an emphasis on pluralism and integration so that no one is left behind, with the implication that any accompanying regulation fits with the increasingly diverse reality of issues. However, the international legal system, in regulating and implementing sustainable development issues and policies, faces challenges with legal pluralism and integration, due to the system's traditional theoretical inclination, which is predicated on the Treaty of Westphalia in 1648 .

Legal pluralism is a well-established phenomenon according to what various and multiple legal regimes are involved in regulation. ${ }^{54}$ However, this growing pluralism is at odds with what could be seen as the traditional conceptualization of international law, which relies on binary divides and core attributes related to State sovereignty, State territoriality and rules mostly mirrored in national systems..$^{55}$ Consequently, the multiplication of actors (beyond the State), scales (besides national/international levels), regimes (including somewhat autonomous regimes branched out from international law, like international environmental law and regimes crossing the differentiation public/ private) and the diversification of governing instruments (non-legal or 'soft' law instruments) challenge the traditional international legal system. This challenge brought about by pluralism, and the associated fragmentation, has led international legal theorists to extensively debate these phenomena and to be predominantly critical of their effects. ${ }^{56}$ Pluralism and fragmentation

54 Nele Matz-Lück, 'Norm Interpretation Across International Regimes: Competences and Legitimacy' in Margaret A. Young (ed.), Regime Interaction in International Law: Facing Fragmentation (Cambridge University Press, 2012). As mentioned earlier, pluralism can relate to having a diversity of actors (or legal authorities), scales or applicable norms/ rules but it can also refer to the different nature of the instruments applicable, including legally binding instruments or 'soft' influential documents. Roger Cotterrell, 'Transnational Communities and the Concept of Law', Ratio Juris, 21/1: 1-18 (2008).

55 Craig Scott, “Transnational Law” as Proto-Concept: Three Conceptions', German Law Journal 10/7: 859-876 (2009).

$5^{6}$ International Law Commission, 'Fragmentation of International Law: Difficulties Arising from the Diversification and Expansion of International Law', UN Doc A/CN.4/L.682, 13 April 2006. 
are considered to bring about potential risks of incoherence, unpredictability, disaggregation for the system and question the centrality of the State $\mathrm{S}^{57}$ vis-⿳亠丷⿵冂vis other emerging local and international actors. ${ }^{58}$ These later actors, for instance, are considered too informal, non-hierarchical and less coherent, compared to the State and its legitimacy. Embracing plurality would then threaten the core values of the traditional system based on the unity, coherence and predictability of the law, considering the multiplication of authorities, applicable laws as well as different levels where regulation could apply as potentially competing. ${ }^{59}$

For these reasons, international legal theory has stirred away from pluralism and fragmentation as much as possible, through a more focused, manageable but somewhat limited approach to what constitutes law, legal actors and scales. This can be exemplified by the reliance to this day on Article 38(1) of the International Court of Justice Statute, listing the primary sources of international law and relying on international conventions, custom and general principles of law as main references on what the law is. In this context where international law reductively considers 'external' sources to the law in its regulation of sustainable development issues, the plurality and diversity normally present in sustainable development are not fully represented by international legal theory in its traditional concepts. Considering the analysis in Section 2, one could then argue that international law, which is rooted in international legal theory, does not fully capture the essence of hydropower projects.

\subsection{The Limited Approach of International Law in the Regulation of Hydropower Projects and its Respective Actors, Scales and Regimes}

Based on traditional international legal theory, the elements (actors, scales and regimes) considered formally by international law are an emerged part of the regulation iceberg. Therefore, this part of the article seeks to consider components that are to some extent not included, or not given priority to, within hydropower projects regulation.

57 Anne-Marie Slaughter, 'Breaking Out: The Proliferation of Actors in the International System', in Yves Dezalay and Bryant G. Garth (eds.), Global Prescriptions: The Production, Exportation, and Importation of a New Legal Orthodoxy (University of Michigan Press, 2002), p. 13 .

58 Nehal Bhuta, 'The Role of International Actors Other Than States Can Play in the New World Order' in Antonio Cassese (ed.), Realizing Utopia: The Future of International Law, (Oxford University Press, 2012), p. 71.

59 Anne Van Aaken, 'Defragmentation of Public International Law Through Interpretation: A Methodological Proposal', Indiana Journal of Global Legal Studies, 16/2:483-512 (2009). 


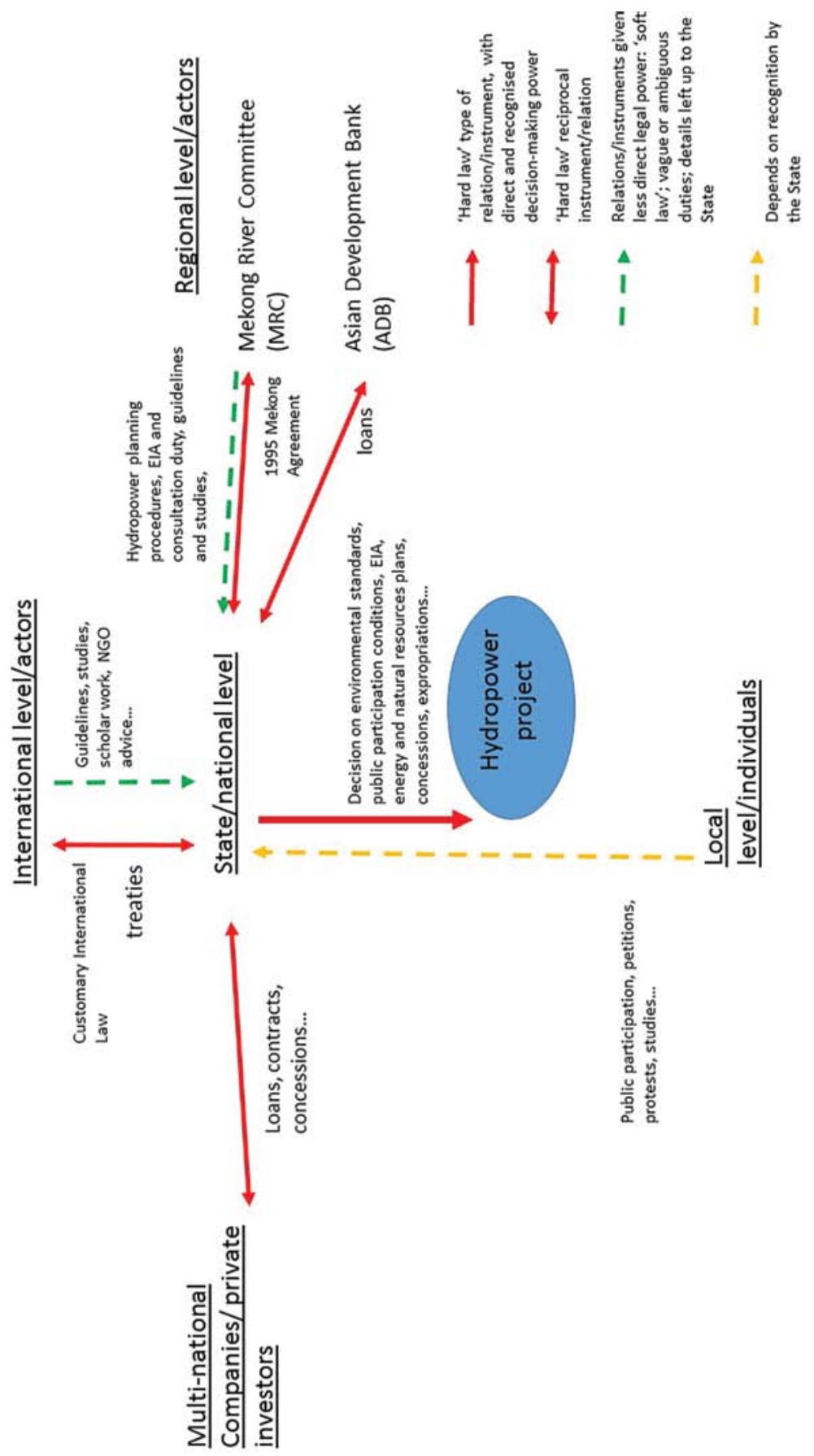


In the proposed schematic, the State is the central actor (and level) of hydropower decision-making. Contracts, loans, treaties and national regulations depend on the State. Some interesting nodes of the schema are the instruments/relations that are designated as 'soft law', 'vague or ambiguous' or 'details left to the State'. Contrary to concession contracts or even loans and investments, these instruments create duties and responsibilities on the State to integrate other regimes (e.g. environmental measures), actors (e.g. public consultation) or scales (Riparian State notification) but to do so in a flexible neither detailed nor assertive - way. For example, the MRC documents (and the international legal duty) requiring to conduct EIAs are detailed to a certain extent, ${ }^{60}$ but the process and documents remain subject to national legislation on EIAs. ${ }^{61}$ Consultation and notification are also substantial and procedural measures set by the Mekong River Commission to ensure cooperation between riparian countries to create an acceptable environmentally and socially driven hydropower project.

At the international level, the legally binding value of certain instruments and duties depend on the country being a party. The 1997 United Nations Convention on the Law of the Non-navigational Uses of International Watercourses, which sets obligations regarding transboundary cooperation, environmental protection, integrated water resources management, no significant harm and equitable and reasonable utilization of shared watercourses like the Mekong, is for now ratified only by Vietnam (out of the four Lower Mekong riparian countries). ${ }^{62}$ Thus, provisions of the 1997 Convention are not applicable in the case of hydropower projects developed in Laos, for instance. Moreover, applicable treaties or customary international law rules - such as the no-harm rule - can be considered too vague and ambiguous to have an efficient and concrete impact on hydropower decision-making and, therefore, fail to integrate environmental and social measures. ${ }^{63}$ That being said, the work of the MRC is not completely undermined or inefficient but still the

6o For further discussion of the International Court of Justice's Pulp Mills-case which established a duty of EIA see section 4.2.

61 EarthRights International, Environmental Impact Assessment in the Mekong Region. Materials and Commentary ( first edition), October 2016, p. 23, https://earthrights.org/wpcontent/uploads/eia_manual_final_o.pdf, accessed 9 May 2019.

62 Convention on the Law of the Non-Navigational Uses of International Watercourses (adopted 21 May 1997) 36 ILM 700 (1997). Vietnam accessed on 19 May 2014.

63 Alistair Rieu-Clarke and Geoffrey Gooch, 'Governing the Tributaries of the Mekong - The Contribution of International Law and Institutions to Enhancing Equitable Cooperation over the Sesan', Pacific McGeorge Global Business \& Development Law Journal, 22/2: $193^{-224}$ (2010). 
consideration of the guidelines and other documents bear less importance in the context of traditional international law and regulation.

Turning to the issue of the involvement of local level actors, international law entrusts the State with most duties and obligations towards individuals. Given the lack of international legal personality of individuals, most of the local level actors' participation has to go through national mechanisms or to be recognized by the State. A very telling exception to this general rule is that individuals can represent themselves in investment disputes on the international level. The State is therefore entrusted to fulfill the rights of individuals with regard to environmental standards, public participation, expropriation conditions and indigenous rights. Due to this visibility of the local actors only through the State and the measures it sets, the duty of public consultation or the right to public participation can be very limited. Hensengerth mentions on the planning of the Kamchay Cambodian dam that NGOs have noted that 'the consultations resembled information meetings rather than open discussions' ${ }^{64}$ Having said that, local actors generally employ non-legal means for participation, such as petitions, protests or informal studies, to convey their interests to decision-makers.

The indirect and State-dependent space accorded to local level and respective actors is disproportionate compared to the primary interest they bear in hydropower projects. While the Mekong River Basin is said to have an underused hydropower potential, the main use of the water by local communities (for fisheries, livelihoods, subsistence) is largely overlooked in favor of energy production. ${ }^{65}$ Besides, the environmental and social impact of hydropower projects is born by local users and communities. ${ }^{66}$

The regional and local levels and actors, like the MRC, are among the "blind spots' which are given less formal recognition by international law. Since such actors have an interest in the hydropower projects in the Mekong River Basin, they should receive greater participatory recognition. Traditionally, local and regional levels and actors defend more environmental and social concerns or aim for a more balanced and integrated sustainable development of hydropower. If international law does not have the means to give more formal space and recognition to these elements, hydropower projects will remain centered on investment, national and State-based decision-making. The plurality of actors, scales and regimes naturally present in this case will not be translated in the type of decision-making regulated by international law. It is

64 Oliver Hensengerth, 'Global Norms in Domestic politics: Environmental Norm Contestation in Cambodia's Hydropower Sector," The Pacific Review, 28/4: 505-528 (2015), p. 527.

65 Williams, 'The Hydropower Myth'.

66 Ibid. 
critical to provide a more pluralist, realistic and sustainable decision-making on hydropower projects as this will allow a better recognition of these actors, rules and scales in judicial claims concerning reparation for harm/damages caused by hydropower.

A wider recognition of 'soft law' instruments, informal actors and nonnational or international scales by international law would allow a substantive amount of the immersed part of the iceberg of hydropower projects regulation and decision-making to be empowered. However, in its current state, international law does not facilitate the accommodation of plurality within hydropower projects planning.

Several projects in the Lower Mekong River Basin illustrate the negative impacts of hydropower projects where regulation has given less importance to a more pluralist approach. The Theun-Hinboun dam, which is the first large dam built in Laos in 1998, involved several actors, among other Norwegian funds, a Thai energy company and the Lao government. ${ }^{67}$ Having monitored the project, International Rivers notes that despite the focus on the economic success of the dam, social and environmental problems have shown the limited, if any, integration and sustainability of the dam project. Similar conclusions have been documented for subsequent dams in the region, such as the Nam Theun 2. Resettlement of indigenous people, environmental and social damages, ${ }^{68}$ the inefficiency of local consultations ${ }^{69}$ and the production of more methane than predicted, ${ }^{70}$ qualify the Nam Theun 2 dam as unsustainable, controversial and damaging. In this case, despite global and regional environmental measures, recommendations from bodies like the World Commission on Dams, the Mekong River Commission (MRC) guidelines, ${ }^{71}$ basin plan, ${ }^{72}$ petitions and the disinvolvement of international donors like the ADB or the $\mathrm{WB},{ }^{73}$ the

67 Geheb, West and Matthews, 'The Invisible Dam', p. 109.

68 International Rivers, Nam Theun 2 Dam, https://www.internationalrivers.org/campaigns/ nam-theun-2-dam, accessed 9 May 2019.

69 Oliver Hensengerth, 'Transboundary River Cooperation and the Regional Public Good: The Case of the Mekong River', Contemporary Southeast Asia : A Journal of International and Strategic Affairs 31/2: 326-349 (2009).

$70 \quad$ International Rivers, The World Bank and Dams; Part. 2: Dispelling Myths of Nam Theun 2, September 2015, https://www.internationalrivers.org/sites/default/files/attached-files/ nt2_factsheet_2015_web.pdf, accessed 9 May 2019.

71 An example is the Mekong RiverCommission, Proceduresfor Notification, Prior Consultation and Agreement, 30 November 2003, http://www.mrcmekong.org/assets/Publications/policies/Procedures-Notification-Prior-Consultation-Agreement.pdf, accessed 9 May 2019.

72 Boer et al., The Mekong: A Socio-legal Approach to River Basin Development, p. 101.

73 Hensengerth, 'Transboundary River Cooperation and the Regional Public Good: The Case of the Mekong River', p. 333 . 
project appears to have not integrated aspects and considerations on environmental and societal concerns.

\subsection{Practical Legal Developments for Pluralism in Hydropower Regulation: The Need to Reconsider Traditional International Legal Theory}

The limitations presented above appear obvious in light of the traditional international legal theory. However, in practice, international law has witnessed developments which aim at incorporating pluralism in the regulation of hydropower.

First, it is worth noting that a more nuanced, dissenting opinion on pluralism and fragmentation has emerged in international legal theory. This suggests that these phenomena are not only a natural evolution of the legal order and a response to the diversification within the issues regulated ${ }^{74}$ but also beneficial for the international system. ${ }^{75}$ Despite a cautious approach towards the potential negative effects of these phenomena, legal scholars and practitioners have broadly acknowledged that pluralism and fragmentation are now part of international law without necessarily questioning the role of the State ${ }^{76}$ or the functioning of the international law system. ${ }^{77}$

Secondly, from a more practical angle, certain developments have occurred outside the traditional frame of international law and reflect a more pluralist approach to regulation. Such emerging developments respond to the need for more attention to environmental and social concerns, the involvement of riparian countries or local population, and the participation of a broader set of actors. For instance, the involvement of non-State actors has grown extensively and it has sometimes been recognised within international law. NGos, international institutions, multinational corporations or indigenous populations have been increasingly participating, both formally and informally, ${ }^{78}$ through reporting, campaigning, advocacy and raising judicial claims. ${ }^{79}$ In addition, the scales at which sustainable development issues, like hydropower, are regulated diversify from the binary national/international perspective.

74 Paul Schiff Berman, 'The Evolution of Global Pluralism', in Roger Cotterrell and Maksymilian Del Mar (eds,), Authority in Transnational Legal Theory: Theorising Across Disciplines (Edward Elgar, 2016), p. 153 .

75 ILC Report on Fragmentation of International Law, p. 5.

76 Slaughter, 'Breaking Out', p. 3 o.

77 Roger Cotterrell, 'What Is Transnational Law?', Law \& Social Inquiry, 37/2: 500-524 (2012), pp. 503-504.

78 Marong, 'From Rio to Johannesburg', pp. 49-50.

79 Paul Schiff Berman, 'Global Legal Pluralism', Southern California Law Review, 8o/6: $1155^{-1238 ~(2007) . ~}$ 
Riparian countries which have an interest in a (national) dam project can share their concerns in the MRC Council or the Joint Committee, or report their opinions on certain procedures through the Secretariat. ${ }^{80}$ In terms of legal regimes and instruments, international legal practice has seen the increase of 'soft' law instruments, especially coming from non-state actors like NGOS, or influential bodies without normative authority. These instruments have been acknowledged and have influenced international law. ${ }^{81}$ Without being given the same normative space and influence as 'hard law', these influential instruments or actors have crafted a space for themselves in hydropower regulation as is illustrated in the previous schematic. The 2000 report by the World Commission on Dams is a non-normative but still innovative and influential document, which sets out guidelines on improved and equitable dam planning. ${ }^{82}$ This document was issued by an ad hoc global multi-stakeholder commission, initiated by the World Bank and the IUCN (World Conservation Union). The report of the World Commission on Dams is emblematic of the realization of social and environmental concerns in the construction of dams and it is a stepping stone in bringing the real costs (e.g. displacement) of projects to the forefront of hydropower planning. ${ }^{83}$

These developments demonstrate the willingness and effort to accept pluralism within international law and the way it regulates hydropower. However, such developments are often thought of as 'spill out' from national boundaries (and from other strict State-based divides at the heart of international law). This suggests that such a phenomenon might be only spontaneous, heterogeneous and practice-based rather than anchored on traditional international legal theory. ${ }^{84}$ Due to a lack of theoretical grounding or homogenous and systematic effort to endorse these developments, such efforts remain limited in their acceptance of diverse actors, scales and regimes. Psarras notes that conceptual frameworks and theories are generally tested in practical contexts to evaluate their appropriateness in dealing with the realities on the ground. ${ }^{85}$ It is thus important for practical innovations and developments to be tested against the existing theoretical framework and consider whether new realities

8o Agreement on the Cooperation for the Sustainable Development of the Mekong River Basin (adopted 5 April 1995) (Mekong River Agreement).

81 John J. Kirton and Michael J. Trebilcock, Hard Choices, Soft Law: Voluntary Standards in Global Trade, Environment and Social Governance (New York: Routledge, 2004), Chapter 1.

82 World Commission on Dams, Dams and Development: A New Frameworkfor Decision-making (London: Earthscan, 2000).

83 Ibid.; Moran et al., 'Sustainable Hydropower in the $21^{\text {st }}$ Century', pp. 11896-11897.

84 Cotterrell, 'What Is Transnational Law?', pp. 503-504.

85 Haris Psarras, 'Law's Authority and Overlapping Jurisdictions' in Cotterrell and Del Mar, Authority in Transnational Legal Authority, p. 97. 
could be integrated and reflected in theory. Here, it is noticeable that 'the multiscalar character of various globalization processes (...) [does] not fit into older conceptions of hierarchies of scale or conceptions of nested hierarchies' of international law. ${ }^{86}$ This gap between international legal theory and the needs and development of the international law system creates tension and instability in the application of the law. In addition, this gap prevents international law from being apt to consider pluralism and provide integration when regulating sustainable development. Scholars point out that policies and regulations anchored in the national/international divide rarely recognize the dynamics that exist across different levels, actors and regimes which are not accounted for by the traditional categories in law. ${ }^{87}$ The Mekong River Basin has been perceived as inadequately regulated by international law while an important, underestimated part of this regulation happens through transnational legal influences, actors and scales. ${ }^{88}$

Sustainable development and hydropower issues require adopting an approach that is flexible and holistic to reflect plurality without being limited by the strict divides and categories within international law theory. ${ }^{89}$ Therefore, a reflection on how to interpret the legal system is now required to best manage pluralist issues, like sustainable development and hydropower..$^{90}$ This is where the importance of $\mathrm{TNL}$ comes into play.

\section{Transnational Law Approach: Opportunities to Provide a Holistic and Pluralist Vision of International Law in Hydropower Developments}

TNL is a theoretical concept providing a vision of international law which extends beyond its traditional categories, by providing an open-ended systems approach. The consideration of pluralism and interlinkages between constitutive elements helps to identify different aspects influencing the regulation of hydropower and better manage sustainable development issues.

86 Saskia Sassen, 'The State and Globalization: Denationalized Participation', Michigan Journal of International Law 25/4: 1141-1158 (2004); Marong, 'From Rio to Johannesburg', p. 76.

87 Moran et al., 'Sustainable Hydropower in the $21^{\text {st }}$ century', p. 11894.

88 Boer et al., The Mekong: A Socio-legal Approach to River Basin Development, p. 61.

89 Mirek Dymitrow and Keith Halfacree, 'Sustainability - Differently', Bulletin of Geography. Socio-Economic Series 40 (2018).

90 Cotterrell, 'What Is Transnational Law?', pp. 503-504. 


\section{Law Regulation}

TNL is a concept that has been given different meanings but, overall, it has been presented with qualities of a systemic approach, while distancing itself from traditional international law attributes. The concept of TNL as a vision or methodological approach could present here a strategy for international law to be more holistic and integrative.

TNL is a relatively recent theoretical concept approached by legal scholars in order to provide a pluralistic outlook of international law. The concept was most notably articulated by Philip Jessup in 1956 and it has since caught the attention of legal and sociology theory. Philip Jessup suggests that TNL aims 'to include all law which regulates actions or events that transcend national frontiers. Both public and private international law are included, as other rules which do not wholly fit into such standard categories.' ${ }^{91}$ He further suggests that actors included in TNL 'may involve individuals, corporations, states, organizations of states, or other groups'.92

The term TNL has subsequently been used by several scholars, including Cotterrell, Berman and Scott but it has borne different meanings, especially due to the flexible nature of the concept. ${ }^{93}$ Some definitions associate the scope of TNL with the combination of international and national law ${ }^{94}$ while others suggest that TNL goes beyond these traditional reference points, adding elements unclassified between the two legal systems. ${ }^{95}$ For Scott, TNL could be defying the existing categories of international law by being 'neither national nor international nor public nor private at the same time as being both national and international, as well as public and private'. ${ }^{96}$

The geographical connotation of transnational has also brought about the idea that TNL can also be a space from a more figurative point of view. This space would take place between regulated elements (such as actors or scales) or space within which dynamics and interlinkages unfold. ${ }^{97}$ For Psarras, the TNL sphere as space can be seen as an intersection or as a meeting point of

\footnotetext{
91 Philip Jessup, Transnational Law (New Haven: YUP, 1956), p. 1.

92 Ibid., 3.

93 Cotterrell, 'What Is Transnational Law?'.

94 Slaughter, 'Breaking Out', p. 17.

95 Cotterrell, 'What Is Transnational Law?'.

96 Scott, “Transnational Law" as Proto-Concept', p. 873.

97 Peer Zumbansen, 'Defining the Space of Transnational Law: Legal Theory, Global Governance, and Legal Pluralism', Transnational Law and Contemporary Problems, 21/2: 305-335 (2012), p. 334.
} 
the different legal orders or regimes involved in the regulation of a given issue. ${ }^{98}$ In addition, TNL has been referred to as a substantive body of law, suggesting that TNL can make up a new field of law and that substantive rules of transnational law can be distinguished. ${ }^{99}$ This is supported, for example, by the argument that some of TNL's primary sources could stem from 'private (individual, corporate or collective) actors involved in transnational relations'.100 Human rights law may also be treated as a TNL regime which has somehow spilled over other specific international legal regimes. ${ }^{101}$ Furthermore, TNL is associated with a 'procedural' nature, ${ }^{102}$ according to which TNL can serve the role of a method or a bridge concerning the interactions between different legal regimes. ${ }^{103}$ In this way, transnational rules would allow the recognition, validation, circulation as well as cross-fertilization of rules across regimes, reducing, therefore, conflict while smoothing out interactions. ${ }^{104}$ In a related fashion, Scott ${ }^{105}$ and Zumbansen ${ }^{106}$ respectively introduce the idea of TNL as an interpretation and a 'methodological lens'. Zumbansen develops this idea as a way to look at the relationship between law and society (and issues pertaining to sustainable development), especially within transnational settings. He does so by studying the interactions between 'building blocks' in which various actors, scales and legal regimes come are engaged. ${ }^{107}$

In general, a broad literature has developed on the TNL concept but as Cotterrell notes, TNL is 'widely invoked but rarely defined with much precision'.108 However, this brief account of definitions and functions of $\mathrm{TNL}$ does suggest a certain flexibility of the concept and an open-ended potential. Another key

98 Psarras, 'Law's Authority and Overlapping Jurisdictions', p. 103.

99 Heyvaert Veerle, 'The Transnationalization of Law: Rethinking Law through Transnational Environmental Regulation', Transnational Environmental Law Journal, 6/2: 205-236 (2017), p. 231.

100 Cotterrell, 'What Is Transnational Law?', p. 501.

101 Matthias Mahlmann, 'Varieties of Transnational Law and the Universalistic Stance' German Law Journal,10/10: 1325-1336 (2009), p. 1326.

102 Cotterrell, 'What Is Transnational Law?'.

103 Veerle Heyvaert and Thijs Etty, 'Introducing Transnational Environmental Law', Transnational Environmental Law, 1/1:1-11 (2012), p. 2.

104 Cotterrell, 'What Is Transnational Law?', p. 502.

105 Scott, “Transnational Law” as Proto-Concept', p. 871.

106 Peer Zumbansen, "Neither "Public" nor "Private", "National" nor "International": Transnational Corporate Governance from a Legal Pluralist Perspective', Journal of Law and Society, 38/1: 50-75 (2011), p. $5^{2}$.

107 Zumbansen, 'Defining the Space of Transnational Law', p. 308.

108 Cotterrell, 'What Is Transnational Law?', p. 500. 
feature here is the theoretical framework which deliberately stays vague and avoids the restrictions of traditional legal theoretical categories of what law is or what should be considered regulation or not. Lin and Scott underline that 'the language of "transnational" is useful and appropriate, perhaps in part because its meaning is contested and its boundaries unclear.109 The concept of TNL is indeed vague and multi-dimensional, or as formulated by some authors, it is a 'hybrid'110 and metamorphic notion, ${ }^{111}$ or even a 'work in progress'.112

\subsection{The Contextualization of Transnational Law with Hydropower \\ Projects: Shedding Light on the Less Formal Actors, Scales and Rules?}

As a conceptual and analytical framework, TNL shows interesting aspects which align with sustainable development, pluralism and the goal of integration. TNL can challenge the long-established international legal system without overthrowing it and offer a different vision for law premised on the existing system. ${ }^{113}$ As highlighted by Lebel and Lebel, a change of vision can start a shift of policy and create change, similarly to narratives about climate change that might have defined the perception of the phenomenon (more than policies). ${ }^{114}$ This could be an opportunity offered by TNL, in spite of its vague nature, that is to shed new light on pluralist and fragmented issues, like hydropower, and (re) consider the role of international law.

In the context of hydropower, issues of strict categorization and clustering are often a problem which leads to ignoring certain actors, scales or regimes during the decision-making process. A strength of $\mathrm{TNL}$, as inferred from its theoretical framework, is that it highlights interrelationships between various, independent elements, beyond the traditional categories that they belong to. These elements, actors, scales or rules/regimes, can then be looked at within a different context or beyond the role and normative influence that is traditionally allocated to them by international law. This part of the article discusses how certain aspects of hydropower projects' regulation could be addressed in a more pluralist way through the use of TNL.

\footnotetext{
109 Jolene Lin and Joanne Scott, 'Looking Beyond the International: Key Themes and Approaches of Transnational Environmental Law', Transnational Environmental Law, 1/1: 23-29 (2012), p. 23.

110 Harold Hongju Koh, 'Why Transnational Law Matters', Penn State International Law Review, 24/4: 745-753 (2006), p. 745.

111 Scott, “Transnational Law” as Proto-Concept', p. 874.

112 Cotterrell, 'Transnational Communities and the Concept of Law', p. 9.

113 Scott, Kurian and Wescoat, 'The Water-Energy-Food Nexus'.

114 Louis Lebel and Boripat Lebel, 'Nexus Narratives and Resource Insecurities in the Mekong', Environmental Science \& Policy, 90:164-172 (2018).
} 
First, TNL's vision of law is broader than that of traditional international law. Jessup refers to the inclusion of 'other rules which do not wholly fit into such standard categories' but have an influence on regulation. This could recognize a more formal normative value and power from unconventional actors and scales. 'Soft law' and other instruments are not "strangers" to international law but TNL arguably promotes a change of mind-set and approach to the rigid divide legal/non-legal.

In term of spatial considerations, TNL could contribute to drawing more attention to the transboundary dimensions of hydropower. TNL could further what international law has started doing - but still need a stronger legal grounding - the establishment of a duty to conduct a transboundary EIA. The use of EIA in case of transboundary risk is now part of customary international law, ${ }^{115}$ especially regarding environmental issues. In the context of the Mekong, the duty to conduct an EIA is promoted both by the MRC and the ADB in hydropower planning on the main stream of the river. However, the EIA is not necessarily carried out in a transboundary way leaving out aspects of the impact causes to other communities and riparian countries which would amount to violation of the international duty to assess transboundary risk through an EIA. ${ }^{116}$ The EIA instrument in combination with the associated Strategic or Social Impact Assessment are the epicentre of sustainable, well-informed and pluralist hydropower projects. The NGO International Rivers conducted a technical review of the EIA produced for the Don Sahong dam in Laos and highlighted that no specific section of the EIA was dedicated to transboundary impacts, despite the dam being built $2 \mathrm{~km}$ upstream from the Lao-Cambodian border. ${ }^{117}$ In a similar fashion, transnational law in its defiance of boundaries would give more formal weight to transboundary public participation. The geographical range for EIAs and public participation are generally set on a more

115 Case Concerning Pulp Mills on the River Uruguay (Provisional Measures) (Argentina v. Uruguay) ICJ Reports 2006, 204.

116 National legislation on EIA does not require the EIA to be transboundary, nor do the MRC Procedures for Notification, Prior Consultation and Agreement (PNPCA). Establishing separate guidelines on Transboundary Environmental Impact assessment is currently work in progress. See the Mekong River Commission, Technical Guidelines for Transboundary Environmental Impact Assessment, $5^{\text {th }}$ Regional Stakeholder Forum Basin Planning and Environmental Management, 20-21 September 2018, Vientiane Lao PDR, http:// www.mrcmekong.org/assets/Uploads/5.-TbEIA.-170918.pdf, accessed 9 May 2019.

117 International Rivers, Independent Review of Don Sahong Dam EIA, 24 February 2014, https://www.internationalrivers.org/resources/independent-review-of-don-sahongdam-eia-8241, accessed 9 May 2019. 
restricted scale due to territoriality issues which justify under international law the duty to organise consultations involving only a part of the local level and actors affected. For example, while Lao municipalities and locals might be able to join in nationally-organized consultations for a dam, the Cambodian communities downstream do not get the same right to participation as there might not be a respective duty on the Lao State.

Another type of categorization that TNL addresses is the role of private actors and associated rules. International legal theory has made an initial clear divide between international private law and international public law. Considering the importance of contracts and concessions with private companies or the loans and investments from private sources, the influence of these instruments/regimes as well as of these actors is quite important. Some of the multinational companies and other private actors have participated in their own 'soft law' regulation with guidelines and codes of conduct. However, this part of private international law is less explored despite a great potential. The lack of attention reduces the depth or multi-dimension of private actors' functioning to an investment-centered role and also gives less normative power to 'soft law' instruments, like codes of conduct.

A final example of what TNL would bring to international law's regulation of hydropower projects is a contextualised perspective and the grasp of what the "big picture" is. Transnational law in its aspiration of being holistic and pluralist is oriented to managing more information cumulated. For hydropower on a transboundary river, especially the Mekong with its great untapped potential, could benefit from a basin perspective where examining the EIA, applicable scales, actors and regimes would be done not only for one project but in conjunction with existing dams and infrastructures. Too often, the regulation and decision-making in hydropower are missing important data due to the focus and assessment of an individual project instead of the cascade of projects often born by one transboundary river. This cements a narrow focus which prevents international law and other factors in decision-making from making a proper and informed assessment of the impact and cost of a project.

These examples of 'blind spots' for which TNL could bring a more pluralist and holistic vision illustrate international law's regulation has provided a narrow perspective of hydropower. The practical settings for each of these cases are still to be determined and further studied but highlighting the gaps left in hydropower regulation by the narrow theoretical basis traditionally set for/by international law is the first step. 
For Marong, the general move of policy towards the objective of integration within sustainable development is creating a timely opportunity to reflect on the role of law in applying and realizing these goals. ${ }^{118}$ The first consideration regarding international law's contribution is its limitations with regard to involving a growing plurality of actors, scales and regimes in the regulation of sustainable development.

The plurality underpinning hydropower projects is not well represented by international law because of the latter's traditional international legal framework and categories. International law maintains a focus on regulation of investment, national level and State-centric character of hydropower projects; this focus has proven to be unsustainable and damaging. The article noted some of the shortcomings faced by international law when accounting for influential actors or scales in hydropower regulation in the Lower Mekong River Basin. The discussion introduced TNL in order to consider a broader, more holistic and pluralist approach to international law pushing the boundaries of what is acknowledged and regulated as a relevant actor, scale and legal regime. ${ }^{119}$

Given the inadequacy of international law to reflect pluralism, the contribution of international law in regulating appropriately the issues related to sustainable development needs to be (re)examined. This is not to say the international legal system is not working or that State sovereignty or the values of unity and predictability should be discarded. However, in the context of sustainable development, adopting a transnational vision of international law regulation could integrate several key actors, scales and regimes needed to create not only economic growth but environmental protection and social wellbeing in order to leave no one behind.

\section{Acknowledgements}

I am thankful to Prof. Alistair Rieu-Clarke for his help in this on-going research.

\footnotetext{
118 Marong, 'From Rio to Johannesburg', p. 22.

119 Paul Schiff Berman, 'From International Law to Law and Globalization', Columbia Journal of Transnational Law, 43: 485-556 (2005), p. 485.
} 